\title{
Corporate Governance and the Performance of Nigerian Banks
}

\author{
John Emmanuel Isaac, Ibenta Steve Nkemdilim \\ Department of Banking and Finance, Faculty of Management Sciences, Nnamdi Azikiwe University, Awka, Nigeria \\ Email address: \\ Johnemmanue1904@gmail.com (J. E. Isaac), steveibenta@yahoo.com (I. S. Nkemdilim) \\ To cite this article: \\ John Emmanuel Isaac, Ibenta Steve Nkemdilim. Corporate Governance and the Performance of Nigerian Banks. International Journal of \\ Economics, Finance and Management Sciences. Vol. 4, No. 2, 2016, pp. 39-45. doi: 10.11648/j.ijefm.20160402.11
}

\begin{abstract}
Although the consolidation and regulatory reforms were initiated in the Nigerian banking industry in 2004, the expected improvement in the operational performance and efficiency in the banking system has not been reflected in the overall health of the economy. It is in the light of the above, that this research examined the relationships between corporate governance mechanisms and performance of banks in Nigeria. This study used secondary data derived from publications of Central Bank of Nigeria (CBN), Nigeria Deposit Insurance Corporation (NDIC) and Security and Exchange Commission (SEC) from 2006 to 2014. The Pearson Correlation was used to assess the relationships between the corporate governance variables and banks' performance. Statistical Package for Social Sciences (SPSS) was used for the analysis. The study observed that a significant negative relationship exists between board size, board composition and the financial performance of banks, while a positive and significant relationship was observed between directors' equity holding and banks' performance. The study concludes that, the directors' equity holding is paramount in boosting the performance of banks in Nigeria. Thus, this study recommends that the regulatory authorities should make sure that all directors own a reasonable amount of equity in the banks they oversee as this will move them to do their best to enhance the performance of these banks.
\end{abstract}

Keywords: Corporate Governance, Bank Performance, Nigeria

\section{Introduction}

Corporate governance has been an issue of serious concern around the world. Several unpleasant happenings made corporate governance a very important topic in both developed and developing countries. The subject of corporate governance became a global matter after the collapse of high profile companies like Enron, the energy giant, WorldCom, the telecom giant and Xerox, the world producer of office equipment, shocked the business world with both the scale and age of their fraudulent practices. These organizations seem to indicate only a tip of a dangerous iceberg (Uwuigbe, 2011).

There were about 89 commercial banks in Nigeria before the consolidation exercise but the activities of these banks caused customers to lose confidence in the Nigerian banking system. According to Akpan (2007), there was lingering distress in the industry, the supervisory structures were inadequate and there were cases of official recklessness amongst the managers and directors, while the industry was notorious for ethical abuses. Poor corporate governance was identified as one of the major factors in virtually all known instances of bank distress in the country. The series of widely publicized cases of accounting improprieties recorded in the Nigerian banking industry in 2009 involving Oceanic Bank, Intercontinental Bank, Union Bank, Afri Bank, Fin Bank and Spring Bank were related to the lack of vigilant oversight functions by the board of directors, the board relinquishing control to corporate managers who pursue their own selfinterests and the board being remiss in its accountability to stakeholders (Uadiale, 2010).

Consequently, Afolabi and Dare (2015) advocate the promotion of the culture of whistle blowing, establishing special courts within the judiciary for the trying of corporate offences, promoting business ethics through moral education. They added that the system should provide protection for whistle blowers to avoid being persecuted for reporting issues that are unethical. Also, Caprio, Laeven and Levine (2008) opined that there should be a revision of bank supervision and corporate governance reforms to ensure that deliberate transparency reductions and risk mispricing are acted upon. According to Sanusi (2010), the current banking crisis in Nigeria, has been linked with governance 
malpractices within the consolidated banks which has therefore become a way of life in large parts of the sector. $\mathrm{He}$ further said that corporate governance in many banks failed because boards ignored these practices for reasons including being misled by executive management, participating themselves in obtaining unsecured loans at the expense of the depositors and not having the qualifications to enforce good governance on bank management.

As a result, various corporate governance reforms have been specifically aimed at appropriate changes to be made to the board of directors in terms of its composition, size and structure (Abidin, Kamal and Jusoff, 2009).

In an effort to address these deficiencies and bridge the gap in knowledge, this study examines the relationship between internal corporate governance structures and banks' performance in Nigeria. The study will be guided by the following hypotheses stated in null form:

1. There is no significant positive relationship between board size and financial performance of banks in Nigeria.

2. There is no significant positive relationship between directors' equity holding and the financial performance of banks in Nigeria.

3. There is no significant positive relationship between the proportion of non-executive directors and the financial performance of Nigerian banks.

In the course of carrying out this research, the researcher met a limitation which is non-availability of 2015 data as they were not published by as at the time this study was conducted. However, the result of the work is not affected as the period covered is long enough to have reasonable findings.

This research work is of great significance to:

a Banks: This study enables the banks to know their stance in relation to corporate governance issues. The board of directors will find this information useful in benchmarking the performance of their banks.

b Bank regulators: This research provides an insight into a better understanding of the degree to which the banks that are reporting on their corporate governance have been compliant with the codes of corporate governance and where they are experiencing difficulties.

c Investors: Investors are well-informed of the corporate governance mechanisms and how they affect the performance of banks. This will help the investors in their investment decisions.

d Academia: This work is also beneficial to Lectures/students who will teach or learn about corporate governance.

e Researchers: The result of this study serves as a reference material for further research in this field of study.

\section{Literature Review}

Corporate governance in the banking sector requires judicious and prudent management of resources and the preservation of resources (assets) of corporate firm; ensuring ethical and professional standards and the pursuits of corporate objectives, it seeks to ensure customers' satisfaction, high employee morale and the maintenance of market discipline, which strengthens and stabilizes the bank (Okoi, Stephen and Sani, 2014 as cited in Afolabi, 2015). Corporate governance as defined by Mayer (1999) is the sum of the processes, structures and information used for directing and overseeing the management of an organization. According to Coleman and Nicholas-Biekpe (2006), corporate governance is the relationship of enterprise to shareholders or in the wider sense, the relationship of the enterprise to society as a whole. The Organization for Economic Corporation and Development (1999) defined corporate governance as a system on the basis of which companies are directed and managed. It is upon this system that specifications are given for the division of responsibilities between the parties (board of directors, supervisory board, the management and shareholders) and formulate rules and procedures for adopting decisions on corporate matters.

Theoretical Review

There is the need to backup this study with certain theories. These theories include: Agency theory, Ethical theory, Stakeholder theory, Stewardship theory.

An agency relationship arises whenever one or more individuals, called principals, hire one or more individuals called agents, to perform some service and then delegate decision-making authority to agents (Bamberg and Klaus, 1987). The scholars both opined that, the primary agency relationships in business are those: (1) between stockholders and managers and (2) between debt holders and stockholders. These relationships are not necessarily harmonious; indeed agency theory is concerned with so called agency conflict or conflict of interest among other things, corporate governance and business ethics.

From the ethicists' point of view, "it is pointed out that the classical version of agency theory assumes that agent (that is, managers) should always act in principals' (owners') interests. In view of the above vis-à-vis the practice of corporate governance, it clearly shows that huge responsibility is placed on the neck of the agents by the principals. To fulfill the ultimate goal of the agency theory by the so-called agents, the need to apply corporate governance is such that it is inevitable to the whole process and operations of the corporate organizations. The recent Nigerian experience of failed banks is a reflection of poor understanding and application of agency theory which led to bad practice of corporate governance.

Ethical theory as it were, is a build-up on the concept of ethics in general. The term ethics comes from the Greek ethos meaning something like morals. It is defined as the systematic reflection on what is moral. By this simple submission, morality is the whole of opinions, decisions and actions with which people express what they think is good or right. Hence, one of the major cardinal thrusts of ethical theory is utilitarianism. It implies, that ethical theory sometimes focuses not on actions but majorly on 
consequences (Jeremy Bentham, 1748-1832) cited by (Uwuigbe 2011). The name utilitarianism is derived from the Latin "Utilis" meaning "useful". Therefore, in utilitarianism, the consequences of actions are measured against values. These values can be happiness, welfare, high productivity, expansion etc. By way of emphasis, the cardinal point in this theory is that, it is essential to give the greatest happiness to the greatest number of people.

So, for a successful practice of corporate governance in Nigeria and beyond, practical application of utilitarianism is a core requirement.

The utility of the shareholders and other stakeholders should be paramount in the minds of the corporate managers. The agents should make all efforts to ensure that principals have satisfactory values with regards to their investment.

Stakeholder theory is a further development on the concept of stakeholder and its relationship to any business corporation. Freeman (1984) offers a traditional definition of a stakeholder thus, "any group of individual who can affect or is affected by the achievement of the organization's objective". The theory states that the organization itself should be thought of as grouping of stakeholders and the purpose of the organization should be to manage their interests, needs and viewpoints. This stakeholder management is thought to be fulfilled by the managers of a firm.

The main groups of stakeholders are: customers, employees, local communities, suppliers and distributors, shareholders, the media, general public, business partners, future generations, past founders, academics, competitors, competitors, regulators and governments.

In other to achieve the overall corporate objectives (with the practice of good corporate governance) managers of business corporations need to understand, appreciate and conscientiously apply the propositions of stakeholders' theory. For every individual or group that have stake in the organization, effort must be made by the so-called agents to preserve and protect their interests for the survival of the corporations.

In the stewardship model, managers are good stewards of the corporations and diligently work to attain high level of corporate profit and shareholders' returns (Donaldson and Davis, 1994). Donaldson and Davis noted that managers are principally motivated by achievement and responsibility needs and given the need of managers for responsible, selfdirected work; organizations may be better served to free managers.

\section{Empirical Review}

Findings of reputable studies on corporate governance and how it affects performance of banks were critically reviewed in this section of our research work. Their views, location, methodology used, results of findings and their recommendations were discussed.

Ayorinde, Toyin and Leye (2012) studied the effect of corporate governance on the performance of the Nigerian banking sector. The judgmental sampling technique was used in selecting the 15 listed banks out of 24 banks that met the consolidation date line of 2005. These banks were considered because they were listed in the Nigerian Stock Exchange. A positive correlation was observed between the level of corporate governance items disclosed by the banks and return on equity which is the proxy for performance. This means that banks who disclose more on corporate governance issues are more likely to do better than those that disclose less. More so, a positive correlation was observed between the directors' equity interest and corporate governance disclosure index. This indicates that individuals who form part of management of banks in which they also have equity ownership have a compelling business interest to run them well. This invariably is expected to improve the performance. But board size has strong negative correlation with return on equity. This implies that how large the size of a board is does not have a positive effect on the level of financial performance of commercial banks in Nigeria but a negative effect.

Uwuigbe (2011), researches on corporate governance and financial performance of banks in Nigeria. This study made use of secondary data in establishing the relationship between corporate governance and financial performance of the 21 banks listed in the Nigerian Stock Exchange. A panel data regression analysis method was adopted in analyzing the relationship that exists between corporate governance and the financial performance of the studied banks. The Pearson correlation was used to measure the degree of association between variables under consolidation. From the analysis: 1 . An inverse relationship between board size and ROE was observed. This indicates a significant negative effect of board size on the financial performance of the listed banks. 2 . Outside directors do have significant but negative impact on bank performance as measured in terms of ROE. 3. A significant positive correlation was observed between directors' equity interest and banks' performance. 4. Banks who disclose more on corporate governance issues are more likely to do better than those that disclose less (a positive correlation).

He recommended that: 1. Effort to improve corporate governance should focus on the value of stock ownership of board members, since it is positively related to both future operating performance and to the profitability. 2. Steps should also be taken for mandatory compliance with the code of corporate governance. Also an effective legal framework should be developed that specifies the rights and obligations of a bank, its directors, shareholders, specific disclosure requirements and effective enforcement by the law.

Ahmad and Mensur (2012) examined corporate governance and financial performance of banks in the postconsolidation era in Nigeria. Data were sought from sixty annual reports of 12 banks for the period of $2006-2010$. The independent samples t-test was employed to analyze data gathered for the study. Multiple regressions (Analysis of Variance) were used to further analyze hypotheses two and three. Findings revealed that Dispersed equity holding does have an impact on the earnings and dividend of banks. Also, board size does not have an impact on profitability of banks. 
The existence of a chief compliance does not significantly enhance profitability of healthy banks in Nigeria. The study recommends the practice of restrictive equity holding in banks, be upheld. Secondly, the need to strengthen managerial policies so that financial performance can be improved is important as the stress test conducted by CBN and NDIC revealed only a positive operational performance. Also, the compliance status needs to be identified in banks that are yet to comply with this provision, so that efficiency and effectiveness in management is complimented with other internal controls.

Afolabi and Dare (2015) studied corporate governance in the Nigerian banking sector: issues and challenges. They used questionnaire to gather the data and analyzed same using Statistical Package for Social Sciences (SPSS). They found that lack of effective corporate governance results in the failure of banks in Nigeria. They recommended the promotion of the culture of whistle blowing.

Ogege and Boloupremo (2014) assessed corporate governance and financial performance of banks: evidence from Nigeria. They employed a regression analysis. The results showed a positive relationship between the corporate governance variables (board size, board composition, corporate governance disclosure index) and the performance of banks in Nigeria.

Akinyomi and Olutoye (2015) examined corporate governance and profitability of Nigerian banks. Regression analysis was employed to analyze the data extracted from audited financial statements of the selected banks. The result revealed the existence of a positive but non-statistically significant association between board composition, board size and profitability. A negative and non-significant association exists between directors' interest and profitability. The study recommends a regular review of corporate governance codes to reflect current social, environmental, technological and economic situations.

\section{Methodology}

Descriptive and quantitative research designs were used in this study. The population for this study consisted of all the 21 commercial banks in Nigeria. The time frame considered for this study was 2006 to 2014 . The sample size was equal to the population.

This study used secondary data derived from the Central Bank of Nigeria Statistical Bulletins, Nigeria Stock Exchange Fact Book and publications of Nigeria Deposit Insurance Corporation from 2006 to 2014.

The average data for 2006 to 2014 was calculated for each variable used in the study. This was done for each of the banks.

The proxies that were used for corporate governance are: Board Size, Board Composition and Directors' Equity Holding. Proxy for the financial performance of the banks is Return on Equity (ROE).

The Pearson correlation was used to measure the relationship between the variables under consideration. The analysis was done with the use of Statistical Package for Social Sciences (SPSS).

The model below is used for the analysis of this work:

$$
\begin{gathered}
\text { ROE }=\mathrm{f}(\mathrm{BOS}, \mathrm{BOC}, \mathrm{DEH}) \\
\mathrm{ROE}=\mathrm{a} 0+\mathrm{a} 1 \mathrm{BOS}+\mathrm{a} 2 \mathrm{BOC}+\mathrm{a} 3 \mathrm{DEH}+\mathrm{e}
\end{gathered}
$$

Where:

ROE $=$ Return on Equity

BOS $=$ Board Size

$\mathrm{BOC}=$ Board Composition

$\mathrm{DEH}=$ Directors' Equity Holding

a1 - a3 $=$ Coefficients attached to the independent variables

$\mathrm{e}=$ Error Term.

\begin{tabular}{|c|c|c|c|c|}
\hline Banks & $\begin{array}{l}\text { Return on } \\
\text { Equity }\end{array}$ & $\begin{array}{l}\text { Board } \\
\text { Size }\end{array}$ & $\begin{array}{l}\text { Board } \\
\text { Composition }\end{array}$ & DEHD \\
\hline Access Bank & 0.034341 & 13.0 & 0.69 & 0.14 \\
\hline $\begin{array}{l}\text { Citibank Nigeria } \\
\text { Limited }\end{array}$ & 0.029618 & 12.62 & 0.59 & 0.11 \\
\hline Diamond Bank & 0.044870 & 12.67 & 0.72 & 0.07 \\
\hline Eco Bank & 0.097752 & 12.0 & 0.56 & 0.19 \\
\hline $\begin{array}{l}\text { Enterprise Bank } \\
\text { (formerly Spring } \\
\text { Bank) }\end{array}$ & 0.029159 & 12.42 & 0.54 & 0.17 \\
\hline Fidelity Bank & 0.031143 & 13.33 & 0.58 & 0.06 \\
\hline First Bank & 0.039760 & 12.69 & 0.69 & 0.05 \\
\hline $\begin{array}{l}\text { First City } \\
\text { Monument Bank }\end{array}$ & 0.058481 & 13.67 & 0.60 & 0.17 \\
\hline $\begin{array}{l}\text { Guarantee Trust } \\
\text { Bank }\end{array}$ & 0.041824 & 12.68 & 0.55 & 0.04 \\
\hline $\begin{array}{l}\text { Heritage } \\
\text { Banking Industry }\end{array}$ & 0.030124 & 13.46 & 0.61 & 0.14 \\
\hline $\begin{array}{l}\text { Keystone Bank } \\
\text { (formerly Bank } \\
\text { PHB) }\end{array}$ & 0.027356 & 15.89 & 0.67 & 0.13 \\
\hline $\begin{array}{l}\text { Mainstreet Bank } \\
\text { (formerly } \\
\text { Afribank) }\end{array}$ & 0.029473 & 15.24 & 0.69 & 0.03 \\
\hline Skye Bank & 0.027735 & 15.0 & 0.67 & 0.11 \\
\hline $\begin{array}{l}\text { Stanbic IBTC } \\
\text { Bank }\end{array}$ & 0.039452 & 13.56 & 0.81 & 0.15 \\
\hline $\begin{array}{l}\text { Standard } \\
\text { Chartered Bank }\end{array}$ & 0.040645 & 14.60 & 0.79 & 0.26 \\
\hline Sterling Bank & 0.142780 & 11.40 & 0.57 & 0.22 \\
\hline Union Bank & 0.022250 & 15.0 & 0.69 & 0.01 \\
\hline $\begin{array}{l}\text { United Bank for } \\
\text { Africa }\end{array}$ & 0.016461 & 12.0 & 0.71 & 0.09 \\
\hline Unity Bank & 0.1525 & 9.67 & 0.51 & 0.25 \\
\hline Wema Bank & 0.167941 & 6.70 & 0.54 & 0.28 \\
\hline Zenith Bank & 0.024380 & 15.0 & 0.59 & 0.11 \\
\hline
\end{tabular}

Table 1. Banks and Average Measurement Variables.

Source: Computed by researcher using CBN Statistical Bulletins and Banks' Annual Report (2006 - 2014).

\section{Apriori Expectation}

Board Size is expected to have a significant positive relationship with Return on Equity. This is due to the fact that an increase in the number of directors should add more expertise and experience to the board's decision-making. This is agreed by the findings of Ogege et al (2014) and Kyereboah-Coleman and Biekpe (2006) among others. 
Similarly, a significant positive relationship is expected between Board Composition (proportion of non-executive directors) and Return on Equity. It is expected that the nonexecutive directors would take the right decisions without fear or favour. As such, a board dominated by non-executive directors should do better. This is supported by the studies of Ogege et al (2014).

Directors' Equity Holding is expected to have a significant

positive relationship with Return on Equity. This is because, having a stake in the banks they run will motivate the directors to do their best to increase the profitability of these banks. This expectation is in line with the findings of Ayorinde et al (2012) and Uwuigbe (2011).

\section{Result and Discussion}

Table 2. Correlation Result.

\begin{tabular}{|c|c|c|c|c|c|}
\hline & & ROE & BOS & BOC & DEH \\
\hline \multirow{3}{*}{ ROE } & Pearson Correlation & 1 & $-.806^{* *}$ & $-.519^{*}$ & $.712^{* *}$ \\
\hline & Sig. (2-tailed) & & .000 & .016 & .000 \\
\hline & $\mathrm{N}$ & 21 & 21 & 21 & 21 \\
\hline \multirow{3}{*}{ BOS } & Pearson Correlation & $-.806^{* *}$ & 1 & $.513^{*}$ & $-.554^{* *}$ \\
\hline & Sig. (2-tailed) & .000 & & .017 & .009 \\
\hline & $\mathrm{N}$ & 21 & 21 & 21 & 21 \\
\hline \multirow{2}{*}{$\mathrm{BOC}$} & Pearson Correlation & $-.519^{*}$ & $.513^{*}$ & 1 & -.253 \\
\hline & $\mathrm{N}$ & 21 & 21 & 21 & 21 \\
\hline \multirow{3}{*}{ DEH } & Pearson Correlation & $.712^{* *}$ & $-.554^{* *}$ & -.253 & 1 \\
\hline & Sig. (2-tailed) & .000 & .009 & .268 & \\
\hline & $\mathrm{N}$ & 21 & 21 & 21 & 21 \\
\hline
\end{tabular}

**. Correlation is significant at the 0.01 level (2-tailed).

*. Correlation is significant at the 0.05 level (2-tailed).

The correlation result shows that board size has strong negative correlation of -.806 with return on equity which is significant at $1 \%$. This implies that an increase in board size will lead to a decrease in profitability (ROE). This means that a large board size does not have a positive effect but a negative effect on the level of profitability in the Nigerian banks. Thus, the result contradicts the apriori expectation of a significant positive relationship between the variables. This result is consistent with earlier studies by Ayorinde et al (2012); Iwuigbe (2011); Harris and Raviv (2005); Lipton and Lorsch (1992); Jensen (1993). They all agreed that larger board is ineffective as compared to smaller boards. However, the result of this study differs from that of Akinyomi et al (2015); Ogege et al (2014) and Kyereboah-Coleman and Biekpe (2006) who argued that there is a positive relationship between board size and firms' value. Also, the result of the hypothesis differs from Zahra and Peace (1989) who concluded that a large board size brings more management skills and makes it difficult for the CEO to manipulate the board.

Board composition (proportion of outside directors) is another variable that recorded a negative correlation coefficient (r) of -.519 which is significant at 5\%. This means that the more the number of outside directors, the lower the performance of the bank in terms of ROE. However, the result is contrary to the apriori expectation of a significant positive relationship between board composition and ROE. This is consistent with the studies of Ayorinde et al (2012); Bhagat and Black (1999), Staikouras et al (2007) and Uwuigbe (2011). They discovered a negative correlation between the proportion of outside directors and corporate performance. However, our findings are different from Akinyomi et al (2015); Ogege et al (2014); Bebchuk et al
(2009) and Pathan et al (2007). They noticed a positive relationship between the variables.

The result shows a strong significant positive correlation of.712 between the directors' equity holding (equity interest) and the performance of the banks under consideration. This result is significant at $1 \%$. The result shows that the more banks' equity owned by the directors, the better the banks' financial performance. This implies that individuals who have equity holdings in the banks they manage have compelling business interest to run them well. This result agrees with the apriori expectation of a significant positive relationship between directors' equity holding and return on equity.

This is in-line with Ayorinde et al (2012); Uwuigbe (2011) and Loderer and Peyer (2002). They observed a positive relationship between directors' equity interest and firms' performance. In contrary, Akinyomi et al (2015) and Lin (2007) found that there is no significant positive relationship between the quantities of stock held by directors and firms' performance.

Hypotheses Testing

Hypothesis 1:

H0: There is no significant positive relationship between board size and financial performance of banks in Nigeria.

H1: There is significant positive relationship between board size and financial performance of banks in Nigeria.

From the analysis, the correlation between board size and Return on Equity (ROE) has a coefficient (r) of -.806, depicting an inverse correlation between the two variables. This indicates a significant negative effect of board size on the financial performance of the sampled banks. On the premise of this result, since the significant effect is negative, we therefore accept the null hypothesis which states that 
there is no significant positive relationship between board size and ROE, and reject the alternative hypothesis.

Hypothesis 2:

H0: There is no significant positive relationship between the proportion of non-executive directors and the financial performance of Nigerian banks.

$\mathrm{H} 1$ : There is a significant positive relationship between the proportion of non-executive directors and the financial performance of Nigerian banks.

From the result of the analysis, the correlation between the variables gives -.519 which is significant at $5 \%$. This means that an increase in the number of outside will result in a decrease in the performance of banks in Nigeria. Based on this result, we accept the null hypothesis which states that there is no significant positive relationship between the proportion of non-executive directors and the financial performance of banks in Nigeria.

Hypothesis 3:

H0: There is no significant positive relationship between directors' equity holding and the financial performance of banks in Nigeria.

H1: There is significant positive relationship between directors' equity holding and the financial performance of banks in Nigeria.

The result shows a strong significant positive correlation of.712 between the directors' equity holding (equity interest) and the performance of the banks under consideration. Based on the result, we therefore reject the null hypothesis and accept the alternative hypothesis which states that there is significant positive relationship between directors' equity holding and financial performance of banks in Nigeria.

\section{Conclusion}

A smaller board size enhances banks' performance while a bigger board size results in poor performance of banks in Nigeria. This means that an increase in board size results in poor performance of the banks.

An increase in the number of outside (independent) directors will result in a decrease in banks' performance as measured with Return on Equity (ROE).

The directors' equity holding is paramount in boosting performance of banks in Nigeria.

\section{Recommendations}

Based on the result of this study, the following recommendations will be useful to stakeholders:

i. Banks should operate with small board size as large board size may negatively affects performance. Therefore, banks should have small board size where the board members are active on their duties to enhance higher performance.

ii. The new code of corporate governance for Nigerian banks should not emphasize increase in the number of non-executive directors in banks to avoid poor performance. Alternatively, executive directors should be considered in reasonable number.

iii. The regulatory authorities should make sure that all directors own a reasonable amount of equity in the banks they oversee as this will push them to do their best to enhance the performance of these banks.

\section{Suggestion for Further Research}

This study used three corporate governance variables (board size, board composition and directors' equity holding) and one financial performance indicator (Return on Equity). Thus, further studies in this area should employ other corporate governance and performance proxies for expansion of knowledge.

\section{References}

[1] Afolabi, A. \& Dare, A. M. (2015): Corporate Governance in the Nigerian Banking Sector: Issues and Challenges. European Centre for Research Training and Development, $U K$, Vol. 3, No. 5.

[2] Ahmad, B. A. \& Mensur, L. K. (2012): Corporate Governance and Financial Performance of Banks in the Post-consolidation Era in Nigeria. International Journal of Social Sciences and Humanity Studies, Vol. 4, No. 2.

[3] Akinyomi, O. J. \& Olutoye, E. A. (2015): Corporate Governance and Profitability of Nigerian Banks. Asian Journal of Finance and Accounting, Vol. 7, No. 1.

[4] Akpan, N (2007): Internal Control and Bank Fraud in Nigeria. Economic Journal, Vol. 95, pp.118-132.

[5] Ayorinde, A. O., Toyin, A., \& Leye, A. (2012): Evaluating the Effect of Corporate Governance on the Performance of Nigerian Banking Sector. Review of Contemporary Business Research, Vol. 1, Pp. 32-42

[6] Bebchuk, L., Cohen, A. \& Ferrell, A. (2009): "What Matters in Corporate Governance?" The Review of Financial Studies, Vol. 22, No. 2, pp.783-807.

[7] http://papers.ssrn.com/so13/papers.cfm on 24th of November, 2009.

[8] Bhagat, S. \& Black, B (1999): "The Uncertain Relationship between Board Composition and Performance." Journal of Global Finance, Vol. 17 No1, Pp. 515-530.

[9] Capiro, G, Jr \& Levine, R (2002): Corporate Governance of Banks: Concepts and International Observations, Paper Presented in the Global Corporate Governance Forum Research Network Meeting, April. 5.

[10] CBN (2009): Banking Sector: The Turmoil, the Crisis. Retrieved from www.Nigerialatestnews.com on 15th February, 2010.

[11] Donaldson, T. \& Preston, L. E. (1995): “The Stakeholder Theory of the Corporation: Concepts, Evidence, and Implications" Academy of Management Review, Vol. 20, No. $1,65-91$.

[12] Freeman, E. (1984): Strategic Management: A Stakeholder Approach. Englewood Cliffs, NJ: Prentice-Hall. 
[13] Harris, Milton and Raviv, Artur, (2005): Allocation of Decision-Making Authority. Paper presented at the Twelfth Annual Utah Winter Finance Conference; on March 11.

[14] Jensen, M., (1993): The Modern Industrial Revolution, Exit, and the Failure of Internal Control Systems, Journal of Finance, Vol. 48, Pp 831-840.

[15] Kyereboah-Coleman, A., \& Nicholas- Biekpe, N. (2006): Corporate Governance and the Performance of Microfinance Institutions (MFIs) in Ghana", Working paper 4330-05, UGBS, Legon.

[16] Lin, Y (2007). Research on the characteristics of Board System and Firm Performance in China: The Comparison between State and Non- State Listed Companies. Asian Social Sciences, Vol. 3, No. 5, pp. 143-155.

[17] Lipton, M. \& Lorsch, J. W. (1992): A Modest Proposal for Improved Corporate Governance. Business Law Review, Vol. 48, No. 1 Pp. 59-77.

[18] Loderer, C \& Peyer, U (2002): "Board overlap, seat accumulation and share prices" Problems between Managers and Shareholders, Journal of Financial and Quantitative Analysis, Vol. 31, Pp. 377 - 397

[19] Mayer, C (1999): Corporate Governance in the UK. A Paper Presented at The Conference on Corporate Governance: A Comparative Perspective, held in University of Oxford on 16th October.

[20] OECD (1999): OECD Principles of Corporate Governance. Ad-Hoc Task Force on Corporate Governance, OECD, Paris.

[21] Ogege, S. \& Boloupremo, T. (2014): Corporate Governance and the Financial Performance of Banks: Evidence from Nigeria. Hyperion Economic Journal, Vol. 2, Issue 2.
[22] Pathan S, Skully, M. \& Wickramanayake, J. (2007): Board Size, Independence and Performance: An Analysis of Thai Banks. Asia-Pacific Financial Markets Vol.14, No.2, Pp 211227.

[23] Sanusi, L. S. (2010): The Nigerian Banking Industry: What Went Wrong and the Way Forward". A Convocation Lecture Delivered at the Convocation Square, Bayero University, Kano, on Friday 26 February, 2010 to mark the Annual Convocation Ceremony of the University).

[24] Soludo, C. C. (2004b): Towards the Repositioning of The Central Bank of Nigeria for the 21st Century. A keynote Address Delivered at the Annual Dinner of the Chartered Institute of Bakers of Nigeria, Held at the Muson Centre, Onikan, Lagos, November 5.

[25] Staikouras, C., Maria-Eleni, K., Agoraki, A., Manthos, D. and Panagiotis, K. (2007): The effect of board size and composition on bank efficiency. Retrieved from http://www.efmaefm.org/0EFMAMEETINGS/EFMA on 13th of October 2008.

[26] Uadiale, O. M. (2010): The Impact of Board Structure on Corporate Financial Performance in Nigeria. International Journal of Business and Management, Vol. 5, No.10, pp 155166.

[27] Uwuigbe, O. R. (2011): Corporate Governance and Financial Performance of Banks: A Study of Listed Banks in Nigeria. $A$ Doctoral Thesis Submitted to the School of Postgraduate Studies, Covenant University, Ota, Ogun State.

[28] Zahra, S and Pearce, J (1989): Boards of Directors and Corporate Financial Performance: a Review and Integrative Model, Journal of Management, Vol. 15, No. 2, pp. 291-324. 